\title{
Philosophical PRACTICE AS A Dialogical danCE. A CHOREOGRAPHIC TYPOLOGY OF PHILOSOPHICAL CONVERSATIONS
}

\author{
FILOSOFÍA APLICADA COMO DANZA DIALÓGICA. UNA TIPOLOGÍA \\ COREOGÁFICADE LAS CONVERSACIONES FILOSÓFICAS
}

\author{
LEON DE HAAS \\ Berufsverband für Philosophische Praxis - Stellenbosch University \\ leon@platopraktijk.nl
}

RECIBIDO: 19 DE MARZO DE 2018

ACEPTADO: 30 DE ABRIL DE 2018

\begin{abstract}
This paper is meant to show that a choreographic typology of philosophical practice is possible and fruitful. In the absence of social research in this field, the author presents an intuitive set of parameters. The parameters will be explained and clarified by applying them to some exemplary practices. The article concludes with recommendations for further research in the field of a choreographic typology of philosophical practice.
\end{abstract}

Keywords: philosophical practice, philosophical counseling, philosophical methodology, meta-philosophy.

Resumen: Este documento pretende mostrar que una tipología coreográfica de la práctica filosófica es posible y fructífera. En ausencia de investigación social en este campo, el autor presenta un conjunto intuitivo de parámetros. Los parámetros se explicarán y aclararán aplicándolos a algunas prácticas ejemplares. El artículo concluye con recomendaciones para futuras investigaciones en el campo de una tipología coreográfica de la práctica filosófica.

Palabras clave: Filosofía Aplicada, orientación filosófica, metodología filosófica, metafilosofía 


\section{Eisenach, Germany}

Last week, I participated, as a supervisor and trainer, in an intensive 5-day philosophical counseling training in Eisenach (Germany). Seven adult students of the BV-PP's educational program $^{1}$ practiced, experienced and observed philosophical (oneto-one) conversations, and reflected upon it. They were inspired and supervised by four experienced members of the BV-PP. Thanks to my participation in this happening, the old habit to sketch a typology of what is happening in philosophical practices was stirred up in me. The habit was born in the time that I was a philosophy student at the University of Amsterdam, in the 1970's. At this philosophy Faculty at that time, the various schools in philosophy were represented, albeit in battle. Not willing to profess one of the schools exclusively, I tried to see and understand their differences and similarities. Since, I have drawn lots of maps of the philosophy landscape, eager to find my way through it. In 2011 I started writing on philosophical practices, and again I couldn't help drawing maps of this 'county' of the philosophical landscape. Last week in Eisenach, I saw my three fellow practitioners having philosophical dialogues with guests, and they saw me. Each of us did some conversations in front of the group. In reflective discussions afterwards, we all tried to reconstruct and understand what the practitioner was doing, and why he or she had done it the way he or she did it. Next to these 'demonstration' sessions, the students carried on conversations with each other, supervised by one of the practitioners. So, this 5-day meeting turned out to be a wonderful opportunity to refine, apply and test my map of the

\footnotetext{
${ }^{1}$ BV-PP (Berufsverband für Philosophische Praxis) is the German professional association of philosophical practitioners. Since 2013, the BV-PP organizes her educational program, called „Bildungsgang”, for philosophers and other professionals to develop their own way in philosophical practice. The program develops in long and short weekends in the course of three years.
} 
philosophy practice landscape ${ }^{2}$. In this paper, I will not present the map; I will expound the underlying 'cartography' of my map drawing ${ }^{3}$.

I look at a conversation in philosophical practice with a topographer's eyes. I see a situation of two (or more) people, meeting somewhere sometime, and having a conversation. In each of them, and between them, things are happening - general human things, but also specific philosophical things. I try to filter out the typical philosophical places, interactions and actions. So, my choreography is a typology. The choreography of the dialogical encounter is a typology of the philosophical attitude and actions. (See figure 2.)

The choreographic typology I am presenting here, is based on intuitive understanding from experience, curiosity, patient arranging, and discussions with colleagues. Until we can dispose of sociological research in the field of philosophical practice, we can use our intuitions and dialogical power to get a more than coincidental and one-sided picture of a reliable and effective 'cartography' to write maps of our landscape. With this paper, I submit a proposal to see the cartography as a set of 'choreographic' parameters. ${ }^{4}$ This attempt is part of a greater project, my dissertation to get a $\mathrm{PhD}$ in philosophy at the Stellenbosch University. The project can be simply shown by means of figure 1 .

\footnotetext{
${ }^{2}$ See my e-books De Haas 2013 and De Haas 2018.

${ }^{3}$ There are some reasons to choose the essay form, i.e., to write in the first person singular. First, discussions in the community of philosophical practitioners about view, attitude and method are still immature and not on a level of developing general standards. So, I cannot speak on behalf of a school or a generally accepted theory and method, which would allow some objectivity and a "we". Second, and more important, I philosophize in a Cartesian and phenomenological tradition, where it is the philosopher's personal meditation that can clarify the "ground" of philosophical thinking.

${ }^{4}$ In De Haas 2017 I presented a cartography, based on a mix of psychological and material concepts.
} 


\begin{tabular}{|c|c|c|}
\hline \multirow{2}{*}{$\begin{array}{l}\text { Parameters for comparing } \\
\text { philosophical practices }\end{array}$} & \multirow{2}{*}{$\begin{array}{c}\text { Philosophical quality of } \\
\text { dialogical philosophy: the } \\
\text { case of narrative-dialogical } \\
\text { maieutics }\end{array}$} & $\begin{array}{l}\text { A scan of narrative-dialogical } \\
\text { maieutics }\end{array}$ \\
\hline & & $\begin{array}{l}\text { Dialogical philosophy in the light of } \\
\text { philosophical paradigms }\end{array}$ \\
\hline
\end{tabular}

Figure 1: Philosophical quality of dialogical philosophy

I am concerned about the philosophical quality of what we are doing in philosophical practice. To be able to explain and clarify the differences and similarities of the various practices, I specify a set of parameters, which are parameters of the dialogical encounter between a philosopher and his guest, from the philosopher's position. So, I will not include the guest's perspective; other kinds of research will be needed to do so. The guest's participation in the 'dance' takes place off the screen of this paper. I concentrate our attention on the philosophical partitioner's presence, attitude and acting. It is not about the effect and effectiveness of philosophical interventions, but about the philosopher's consciousness of his presence and acting in a dialogical encounter. For that, we need such a set of parameters, and we will have to apply them to existing practices, to test their applicability. As it is all about the philosophical quality of our practices, we need a criterion to determine it. In my opinion, there is only one convincing criterion, i.e., a well-founded 'review' of our practices in the light of philosophical paradigms ${ }^{5}$. It is my dissertation project, to do this in a case study, namely my own way of philosophical practice (called "narrative-dialogical maieutics"). In the present paper I focus on the parameters. I will explain and clarify them in the view of this kind of practice.

\footnotetext{
${ }^{5}$ In Western philosophy, it is problematic to talk of paradigms. From ancient beginnings, philosophy has many voices, which are not univocal. There is not just one tradition, but there are more. In the broad field of philosophy, no one can claim to possess the one and only right view of philosophy, although each of them is inclined to do so. In this essay I look at philosophy from a Socratic point of view, i.e., the Socratic paradigm as updated by the phenomenological and linguistic turns of 20th century.
} 


\section{An intuitive set of parameters}

Figure 2 shows a core choreography of a dialogical encounter in philosophical practice. At the center is the relation between two people, the one called 'philosopher', the other called 'guest'. The figure pictures the relation from the philosopher's perspective in the encounter. He is saying ' $\mathrm{I}$ ', in conversation with 'you'. That I am labeled 'philosopher' and you 'guest', indicates differences in roles, expectations, actions, dialogical dynamics, and balances of power. Our relation in the encounter is typified by the dialogical balance, as determined by the philosopher, his attentional focus and his acts. All this is being inspired and steered by what he wants in this relation. In addition to the choreographic parameters, two other parameters are influencing the dialogical dance. First, there is a situational parameter, the 'habitat' of the dialogical encounter, the non-philosophical embedding. Second, there is assessment of the encounter as a philosophical one, its philosophical quality.

In the following, each of these parameters will be specified step by step. I will explain and clarify them by referring to practices that I consider to be exemplary of different typical positions in the landscape of philosophical practice; Oscar Brenifier ${ }^{6}$, Anders Lindseth $^{7}$, Ran Lahav ${ }^{8}$, and myself ${ }^{9}$. In addition, I refer anonymously to the 'choreography' of the conversations in Eisenach $^{10}$.

\footnotetext{
${ }^{6}$ You can see videos of Brenifier's philosophical conversations on YouTube.

${ }^{7}$ See Lindseth 2005.

${ }^{8}$ You can see videos of Lahav's philosophical conversations on YouTube. See also Lahav 2016a and Lahav 2016b.

${ }^{9}$ See De Haas 2018.

${ }^{10}$ In the following, I will judge positions like Brenifier's and Lahav's from my point of view. My judgement does not mean that their ways of practicing philosophy is not "good" or not "philosophical". I recognize their views and methods as being philosophical. I judge their views and methods to mark out the "piece of land" in the landscape of philosophical philosophy where I am situated.
} 


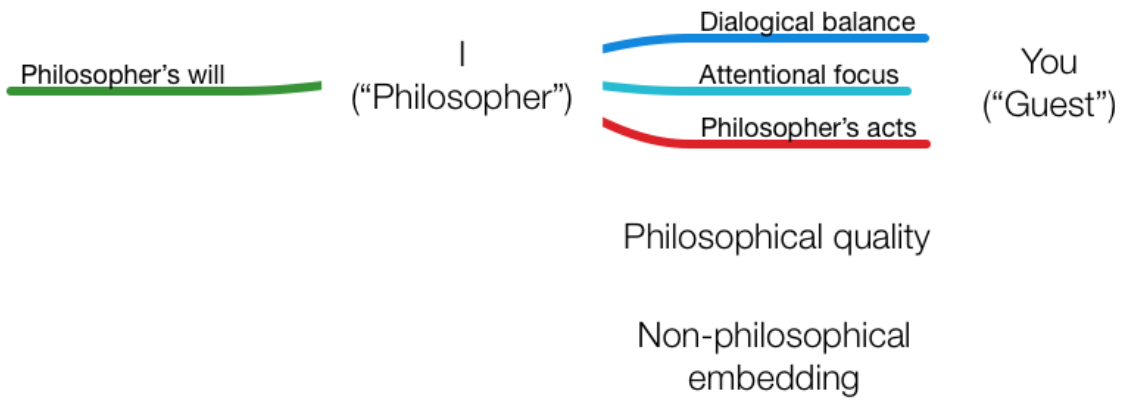

Figure 2: Dialogical-interventional parameters (from the philosopher's position)

\section{Dialogical balance}

Where are we in our dialogue, more on my side of the relation, or more on yours?

We meet somewhere sometime, by chance, or by appointment, as friends, or as passers-by, or as client and service provider. We get talking about something. On purpose or in a sudden brainwave, I decide to change the conversation into a dialogue, my everyday consciousness into philosophical attention. You tell your story, I listen. You tell your story, I ask questions, you answer. I say things, I assert things. Now you are the speaker, then I am the speaker, back and forth. We are related through our speaking and listening. Each of us is a pole in the relation. Where is the centre of gravity in the balance of these poles? Who tips the balance in his direction? Who draws the attention? Who dominates the talking? Who leads the dance? 


\section{Surgical interventions}

In Eisenach, we had the chance to see and discuss how the four of us practitioners differed in leading the dialogical dance. Two of us took the lead and pulled the dance. They determined to a large extent the content and direction of the conversation. They influenced the guest and his or her story strongly. These philosophers are like surgeons, busy cutting in the other's flesh, eager to implant a given (philosophical) truth or insight in the other's thinking.

Brenifier is a philosophical surgeon. He leads the dance very decided. Right at the beginning, he demands a question. If you don't have one, he will not go on with the conversation. And as soon as you formulate your question, he focuses on one or more words of the question, and he will stick to them. Step-by-step, asking dual-logic questions all the time, and demanding clear decisions in this logic dualism, he goes on from one statement to another, from one term to the next, until there is a clear and unequivocal answer to the initial question.

With Brenifier, the compulsion is in the questioning and in the logic. With other practitioners, the compulsion is in making a theme of the guest's words and pronunciations. For instance, at the beginning of the encounter the guest indicates that he is wondering who are actually his real friends. The philosopher identifies a theme, friendship. He recognizes it as a philosophical theme, because it has been discussed in antiquity by Aristotle and Epicurus. By doing this, he pulls the dance to himself. The guest is supposed to follow his movements.

In a certain sense, the philosopher's mind set is brought in here as a a priori system of meaningful concepts and statements (like Aristotle's concept of friendship) or a apriori procedure to determine the true meaning of a concept (like Brenifier's imperative questioning in a dual logic way). The mind set is apriori 
'true', and is applied to the guest's experiencing and thinking. ${ }^{11}$ It constitutes these experiences and thinking, at any rate, the philosopher tries to operate that way. In extreme cases of this kind of philosophizing, the guest's story, her experiences and thoughts, are being treated as a mere function of the philosopher's operation. The justification of such a mode of operation is the alleged universal value of the applied philosophical mind set.

\section{Maieutic interventions}

The other two of us, in Eisenach, followed the dance partner. From the beginning, the word is up to the other. The philosopher's questions and remarks are meant to encourage the other to tell his or her story. In the dance, the guest leads, and every now and then the philosopher intervenes, just to support the guest in his or her leading. Actually, this philosopher intends to be a philosophical midwife, like Socrates. His attitude and aim is, to support the other in exploring and discovering his or her own questions, issues, thoughts, experiences.

In general, we can say that a so-called narrative approach in philosophical dialogues places the centre of gravity of the balance in the other. The philosopher invites the other to tell his or her story, and he gives a lot of room for that. His motivation in the dialogical encounter is to be maieutic.

Both Lindseth, Lahav, and myself have this maieutic attitude. We offer a setting, a space of attention, within which the guest has all the time to express herself. It is our intention that the guest, by herself, uncovers what still is covered. My questions and remarks

\footnotetext{
${ }^{11}$ In this context, I mean with apriori mind set the philosopher's concepts, theories and procedures that are pre-existing to the guest's experiences and thought, and that are being considered by the philosopher to be true and valuable by itself, and ideally suited to understand the guest's questions, experiences and thought.
} 
are meant to invite the guest to tell, in her own words, what she remembers that she had experienced in the situations and events she wants to explore. I am like a mountain guide who is not out to lead the other person through the landscape, but to have this person find his way by himself.

\section{Hybrid interventions}

Actually, Lindseth and Lahav change between leading and following. They surely give space to the guest's own experiences and story. But at any given time, they introduce a surgery. Lindseth scoffs at a theme, and he leads her in the theme exploring direction. Lahav scoffs a specific perspective to view the world, and he leads her in the perspective exploring and changing direction. At the end, their interventions are not maieutic, but surgical. Even though they are more friendly and less compelling than Brenifier's interventions, they are surgeries. The philosopher leads the dance; the dialogical balance tips to the philosopher.

\section{Attentional focus}

Where am I, where is the focus of my attention?

Intrinsic in the dialogical dance is the philosopher's attention. The dialogical balance is a balance of attention. Where is the focus of my attention? Is it close to you? Or is it turned inwards, close to myself, being full of my own impressions, ideas, images, conceptions? Am I in here, or am I with you, with your expressions, your words, your story, your recollections, your experiences, with the situations and events you are sharing with me? 


\section{Inward}

The philosopher who is scoffing so-called philosophical words, eager to make a theme out of them, is mainly focused on his own thoughts. Whatever the guest tells, his attention is already programmed to advance his own themes. Like a raptor, Brenifier preys on the guest's saying, willing to devour him in his iron logic. What matters, is the logic of Brenifier's questioning. The guest's attention is coercively pulled in the philosopher's focus. Like a warm and dedicated carer, one of the practitioners in Eisenach arches over to the guest, to seduce him to go along with her in her philosophical concept. The guest wants to talk about issues of friendship, but he is taken on the trip the philosopher orchestrates. On a caring and loving way, the guest's attention is pulled in the philosopher's focus. Like a wise father, with a friendly but decided hand, one of the other practitioners in Eisenach brings his guest to see structures in what he experiences and tells. On a patient teaching way, this philosopher pulls the guest's attention towards his structure searching and identifying bias.

\section{Outward}

Being a narrative and maieutic set philosopher I turn my attention towards the guest. My focus is not inside myself, but wanders around in the guest's words, which I do not arrogate, nor digest in my own story. I surrender to the narrative of the other. My attention is occupied by what the other says. Through the guest's words, I experience the other's experiences. It happens what Levinas called a occupation (Levinas 2013). The dialogical movement goes from the guest to me, and so goes the experiential and the attentional movement. My focus is with the other, I am from my balance, and "passively" (Levinas) filled with the other's (remembered and narrated) experiences. Of course, I am not wiped out, even if that 
might happen sometimes. Not me, but my attention is occupied, be it that, hopefully, I have the power to find my own way in the landscape of experiences that is being opened up for me by the other's words. I am introduced into the other's world of experiences, and can look around there. Now I am able to be surprised, to ask questions, and to share my impressions. Of course, these moments of talking are inward movements, but they occur there, outward, in the other's narrated experiences, which I experience.

Lindseth and Lahav are dedicated to their guest. Lindseth is more outward in supporting his guest to tell her story. Lahav is more inward in following his path in search of perspectives and perimeters (Lahav 2016 a). I am rather straightforward in the outward orientation of my attention. I am eager to avoid to hold on to my own thoughts, ideas and associations. I train the inwardoutward movement of my attention all the time.

\section{Inward concepts versus outward metaphors}

Concepts and metaphors are mighty weapons in a dialogue. They draw the attention of both the philosopher and his guest. Those practitioners who want to lead the dialogical dance, and are inclined to stay in their own philosophical thoughts and principles, like to build concepts. A guest talks about her friendships, the philosopher hears a philosophical concept, the dialogical attention is being drawn from the guest's memories and feelings towards the concept of "friendship", as it has been defined in the history of philosophy. Through that, the guest is seduced to leave his own world of experiences and thinking. Now, his attention is occupied by the philosopher's train of thought. That is what philosophical concepts do; they turn the attention away from the outer world - be it the present world or a world that you experienced once and that 
you are recollecting now - and fix it inward in an activity of defining concepts.

As Nietzsche noticed (Nietzsche 2015; De Haas 2015), in understanding our world we are not condemned to (philosophical) concepts; our languages have the powerful possibility to speak in metaphors. Other than concepts, metaphors do not catch an experience in lifeless meanings; thanks to their sensory power, they move our experience and imagination. The above mentioned colleague, eager to find structures in the guest's story, is a master in offering strong metaphors to his guests. He invents them himself; he is very creative in it. His metaphors release his guest's thinking, and stir the other's imagination.

Not uncommonly, philosophers use metaphors, but forget their lightness. They take them too literally, and use them as mere illustrations of the concept they want to sell. It belongs to the art of maieutic and outward philosophizing, to create and offer metaphors on the spot - and leave them behind in the dialogical dynamics, like stepping stones on a mountain walk.

\section{The philosopher's will}

What am I aiming at, what do I want?

Why do I do what I do, when we are in our philosophical dialogue? What do I want in this encounter? Do I strive for some effect or value? Do I want you to achieve some goal - my goal? Do I want you to change - maybe by some philosophical standards?

In what precedes in this paper, it might be clear that a philosophical practitioner's participation in a dialogical encounter is not a mere coincidence. To a considerable extent, his or her presence is dominant in the conversation. Should that be more than clear in Brenifier's attitude and way of acting, it is also the case in my 
maieutic attitude, and in the behaviour of the "warm and dedicated carer", mentioned above. We all want something.

Recognizing and reducing

Brenifier wants his guest to answer his questions, which aim at decisions in a dual logic. He does not accept his guest answering with stories about experiences (Q. "Are you sure about that?", A. "When I was in Paris, we ..."), or with modal logic, like maybe, "probably' (Q. "Are you sure about that?", A. "I don't know; maybe."). Right from the start, Brenifier is clear about what he expects, and he is very definitive in it. He wants a question. If you do not have a question, he does not go on until there is a question. And it must be a question that it clear enough to be treated in his dual logic questioning machine. So, right at the beginning he forces the guest in his way of thinking. The other has one or another issue in mind that he wants to talk about. This what he has in mind, must become a treatable question. When being asked about a statement of his, the guest might hesitate, or some narrative association might have been called up. Brenifier does not accept such kinds of answers, and forces the other back in his logical trail.

The above mentioned practitioner who looks for structures in the guest's story is set to see structures. Whatever the other says, he tests it against his concepts and pictures of systems and structures. Many a philosophical practitioner is busy identifying allegedly 'philosophical' themes and concepts, like friendship, or thankfulness, or authenticity. Whatever he hears his guest telling, he wants to hear some philosophical theme or concept. All the time, he is busy recognizing some such theme or concept in the guest's words. Even though he is not as rigid as Brenifier, like Lahav, he wants his guest on his side of the dialogical balance, and to follow the philosopher's track. The guest's words must be reduced to the philosopher's themes and concepts. Lahav is focused 
on recognizing perspectives and perimeters, even though he allows his guest to tell about experiences, and to dwell on some biographical association, or to hesitate in answering a question, and never will force his guest to follow his preferred philosophical track.

Receiving, perceiving, and experiencing

When we see Lindseth talking with a guest, we see someone listening to what the other has to say, not someone who wants to hear something specific. In Lindseth's own words, it is his attitude to get an impression of the other's expression. In figure 3 we see a photo of one of the pictures he draws when he wants to make it clear (see figure 3 ).

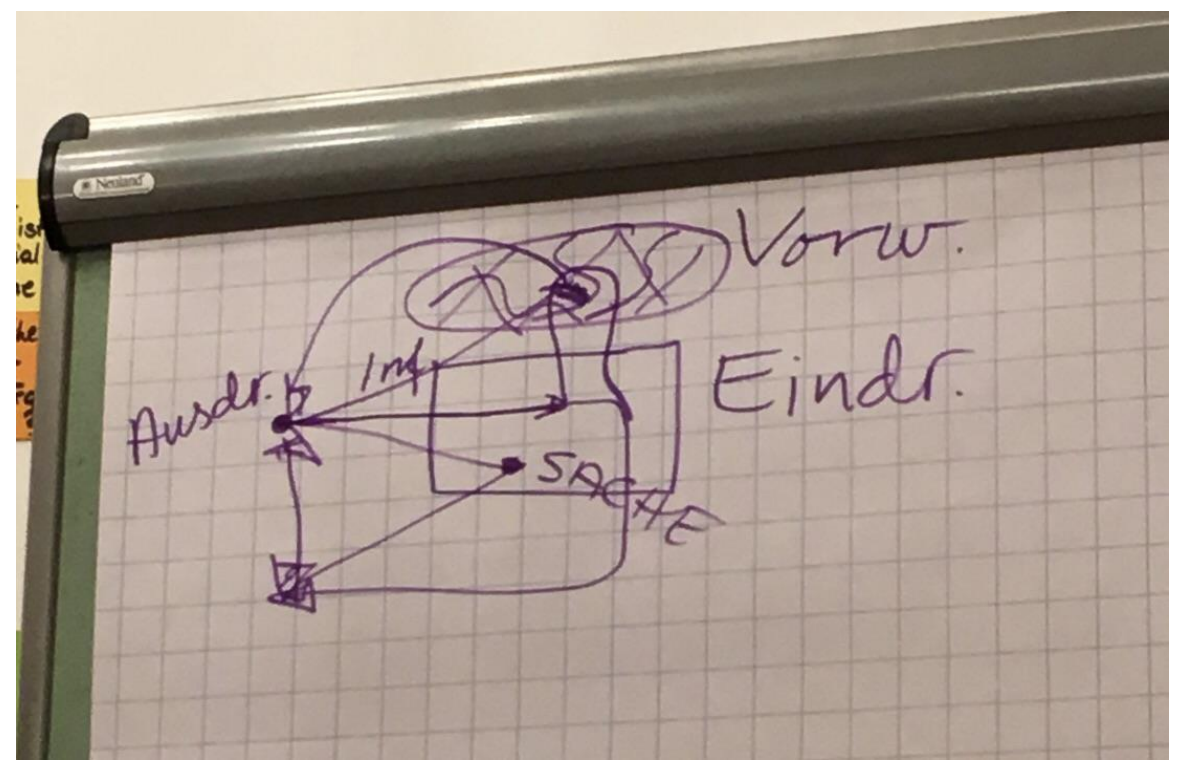

Figure 3: Anders Lindseth's picture of the dialogical relation in philosophical practice 
Philosopher and guest are in a conversation. I, the philosopher, am on the right in the picture. You, my guest, are on the left. You tell me the story of your experiences; you express yourself ("Ausdr.", Ausdruck). I get impressions ("Eindr.", Eindruck) from your expressions. What we are talking about, is the thing ("Sache") that matters you. In the conversation, I express my impressions from your expressions, and you get an impression from my expressions. Meanwhile, we both have foreknowledge ("Vorw.", Vorwissen) about the matter we are talking about. Each of us refers to that foreknowledge. It's me, the philosopher, who is supposed to be conscious of the foreknowledge, and is partly focused on 'weighing' its influence and importance. For me, the philosopher, my foreknowledge is not only bias in my attention for you, it can also be a source of themes and concepts that might be relevant to your, i.e. the guest's story and concern. So far Lindseth.

I agree with Lindseth to some extent. It is also my attitude, to be open to what the other is expressing. I want to be impressed by her or his expressions. Both to Lindseth and me, this attitude is not a technique. Empathy happens, but it is not a technique that can be trained and applied, like in care professions nowadays. I prefer to use Levinas' words here. He talks about an event that happens to me in an encounter with another human being. "More passive than passive" the other's suffering happens to me; I am being possessed by it. I am powerless, until I resurrect and bear all responsibility for it. (Levinas 2013) This "being possessed" and this "bearing all responsibility" are choices; it is a decision. It is the 'ethos' that carries and feeds my presence and acting in dialogical encounters. Where Lindseth, at any moment, proceeds to identify a philosophical theme or concept, I don't. During the conversation, I reflect upon my attention and thinking, attentive to spot any tendency to inward-looking, and to give my receptive attention to my partner in dialogue. 
The inevitability of philosophical bias

Whether the philosophical practitioner projects his logic, theme or concept on the screen of the guest's words, or he is open to get and receive impressions of the guest, in the dialogical encounter we all are biased and have specific expectations of what should happen. It is impossible that you do not have one or another expectant attitude, full of ideas and beliefs about what should happen in a philosophical conversation. The question is whether we realize. Many a philosopher has a blind spot as to the beliefs that carry his philosophical acts. As usual with beliefs, the believer cannot but think that his belief is the very realty itself. Of course, I am convinced that "real" philosophy does not identify and make themes and concepts, but listens and perceives what appears in my world of experiences. Being conscious of your own "grounding" beliefs, especially of the fact that they are beliefs, makes you accept the fact that colleagues might have different beliefs. In the landscape of philosophers and philosophical practitioners, we are believers, even though our actions are technically and methodologically clear and well-founded. Unfortunately, too many philosophers and philosophical practitioners keep thinking that their idea of philosophy is reality itself, and that their colleagues, with different ideas of what philosophy is, believe in a deviation. Here, conversation can just be debates, a battle between positions, not a dialogue. In the mentioned gathering in Eisenach, in one of the reflecting discussions about a dialogue in front of the group, a kind of a debate arose between Lindseth (in the group) and me (in front of the group) about our beliefs in doing philosophical practice. Lindseth proposed to change the staging, and to have a dialogue in the philosopher-guest setting in front of the group. The conversation changed from debate to dialogue. We did not defend positions anymore; we were sharing experiences and ideas, and we were thinking together about what matters to both of us. 
The special feature of both Socrates and Wittgenstein is, that they brought in their underlying belief in the philosophical investigation, and that they put it on the line. For both, philosophy was not in identifying and making themes and concepts out of other people's words. Quite the contrary, they investigated alleged claims of 'truth', by questioning the semantics of the words that were used in those claims. Their methods differed, but their philosophical dispositions were kindred. When we distinguish Socrates' dialogical encounters in Athens from Plato's meta-philosophical attempts to understand and ground what was happening in those encounters, we can say that Socrates did not discuss his belief in maieutics and in the aporia. These grounding beliefs of his were his stake in the dialogical investigation (beside the stake of the dialogical partner's truth claim, of course). Again and again, every single dialogical encounter was a place to test the power and tenability of the belief in maieutics and aporia. As we know, not every dialogue furnished evidence of that power and tenability. Wittgenstein did the same. To him, the founding beliefs concerned the 'normal' social use of words, as opposed to 'abnormal', especially so-called 'philosophical' use of words. In his method, he used the technical terms language game, form of life, and family resemblance. He avoided to theorize about these terms. To a large extent, the many years' process of arranging and re-arranging his notes and remarks was a process of avoiding any semblance of theory. His method of 'showing' language games is the way he proved the power and correctness of his grounding beliefs - again and again, in each single language game description.

In Socrates' and Wittgenstein's footsteps, I want to be explicit about the grounding beliefs of the way I philosophize, and I hesitate to theorize about them. For me, too, the proof of the pudding is in the eating, again and again. 


\section{The philosopher's acts}

What am I doing, what kinds of things?

Meeting you, and in conversation with you, we cannot help but interact; I cannot help but influence you, and being influenced by you. I ask you questions, and I respond to what you are doing, to what you tell me, to how you tell it me. With my presence and actions, I am intervening in your presence, in your attention, imagination, thoughts, ideas, recollections, feelings, and the course of your thinking. What am I doing, when we meet and enter in a philosophical dialogue?

You can recognize a philosopher's will, dialogical attitude, and attentional strategy in what he does in a conversation. You can see it in the way he asks questions, in the kind of questions he asks, in the things that he claims, in the comments he makes, in the goal that he pursues, in the focus of his attention - in short, in his steps and moves in the dialogical dance.

\section{Diagnosing and advising}

In the philosophical conversations in Eisenach, all the four of us asked questions and made remarks and assertions, to aim at what we thought was the rationale of the conversation. What we did, was done in the light of this rationale. As our rationales differed, our actions differed. The 'system therapist' tried to have the guest see his issue in the light of structures. His questions, remarks, and statements aimed at establishing 'structural insight' in the guest's mind. The other colleague, a caring and helpful philosopher, tried to diagnose the guest's issue in traditional philosophical terms, and focused on finding ways out of the guest's problematic situation. Here, the philosopher's actions aimed at recognizing philosophical themes and concepts, and at helping the guest in thinking of alternative, healing actions in her daily life. The third colleague 
started a conversation by supporting his guest to express her experiences in what mattered to her. He continued supporting her to tell her story in her own words for quite a long time. His questions and remarks served this purpose. But then, he focused on a classical philosophical theme he thought he could hear in the words of his guest.

In all these cases, the philosopher is focused on recognizing his own image and concept. Brenifier's focus is not on classical philosophical themes and concepts, but on spotting vague, hybrid word meanings in the guest's statements, in order to apply his dual logic, and to get clear definitions and choices. Practitioners of the so-called "neo-Socratic moderation" 12 do the same. They have a specific procedure in mind, a kind of protocol to proceed in a philosophical conversation. Some neo-Socratic practitioners stay with the guest's experiences for a longer time than others, but at the end all of them focus on words in the guest's story that can be candidates for becoming concepts to define. So, to all these philosophers the guest's words are a screen to project whatever philosophical bias on, be it themes, concepts, models, structures, methods or procedures.

\section{Maieutics}

Is it possible to avoid any bias when you are in a dialogical encounter and you are in the position to direct and control the course of the conversation? It is possible not to? It depends on your attitude, your 'ethos', and on your power the leave the comfort

${ }^{12}$ Neo-Socratic moderation of conversations was founded at the beginning of 20th century by German neo-Kantian philosopher Leonard Nelson. He formalized Socrates' dialogues, as described by Plato, and made a conversation method out of it. Up to the present day, people apply this - often modified method to group conversations. Some apply it also to 1-1 conversations in philosophical practice. 
zone of the thoughts and mind pictures you already have. The paradigmatic metaphor for this way of philosophical acting is Socrates' maieutics, his philosophical midwifery. This is both an attitude (not the philosopher but the interlocutor is the one who gives birth to his or her own thoughts and insight), and things to do (asking questions, and making remarks and statements). Unlike diagnosing and advising colleagues, the maieutic philosopher asks questions just to support the interlocutor to tell his or her own story, i.e., to find her own words to express her own experiences. The philosopher's contribution to the conversation is meant to support the other's narrative and to provoke better words, i.e., words that express the experience clearer and more accurate. At the end, it is up to the interlocutor to decide what is 'clearer' and 'more accurate', but the philosopher can try to stimulate and challenge the other.

Given one or the other philosophical attitude, the philosopher asks questions and makes statements, but the content, quality and effect of his words depend on the (either diagnostical or therapeutic or maieutic) nature of his or her attitude. When, for instance, a maieutic philosopher brings in an analysis of the other's saying, this is meant to be a provocation. When his diagnosing colleague is doing the same, it is meant to be a serious option for the guest.

\section{Philosophical quality}

Why should I be right in calling my practice 'philosophical'?

What we do, or at least what I do, I like to call it philosophical. But what gives me the right to claim that? Can I prove it? If so, how do I prove it? 
Recently, in the Deep Philosophy group ${ }^{13}$, we talked about ways to develop further the contemplative companionship sessions ${ }^{14}$. I put forward the idea to view a painting or listen to music. I do it in the philosophy groups in my own practice, which, by the way, are not contemplative companionship. I consider it a fruitful way to start the philosophizing with perception and experience, and to have understanding and insight develop from without this perceiving and experiencing relation with the piece of art. Indeed, this is a phenomenological way to understand the world. Lahav was opposed to my proposal. He took the view, that the philosophical quality of contemplative philosophy is in the text. Without a philosophical text a companionship session cannot be philosophical. In my opinion, however, the philosophical nature of a philosophical conversation is not in the text, but in the philosopher's (and the guest's) attitude and dialogical relation. Here, we find an important difference in identifying the philosophical quality of philosophical practice. Is it in the texts, themes, concepts, method, and arguments, or is it in the dialogical attitude and relation?

${ }^{13}$ The Deep Philosophy group is a small group of philosophers who gather around Lahav's idea of contemplative companionship sessions. They practice this kind of companionship on a regular basis, both in video conferences and in physically real encounters. In retreats and on conferences other people are invited to join the sessions. See Lahav 2016 b.

${ }^{14}$ Contemplative companionship is a way to read philosophical texts in another way than the way we are used to. Usually, we read philosophical texts to identify its object and the author's position; we fillet it, debone it, judge it, sentence it, or, on the contrary, we thank the gods for having sent us this wonder of deepest insight. In contemplative companionship, a text is not an object of criticism or worship, but the author's expression of his experience, insight, inspiration. Reading the words, you surrender, and have the words leave impressions in your mind and soul. The text is doing something with you and you let it happen; you are not appropriating the text with your processing instruments. 
Semantic filtering: meaning, sense, value, and explanation

What is at stake in philosophical conversations? To answer this question, it is helpful to look at the "substance" of philosophical conversations. What is being shared here, are words. And what matters, is the meaning of the words. What is at stake in philosophical conversations, is that we want to understand some issue, and that the understanding is fixed to words and sentences. Typical of issues in these conversations is that their meaning is not obvious. For instance, that you are confused by your sister's attitude towards you, is not just a property of the sister's acting. Or that you are worried and angry about your neighbor's right extremist statements is not just a property of the neighbor's acting and speaking. We are projecting meanings, values and explanations on the world all the time. Too often we hold our projections for the real world. Those philosophical practitioners who consider philosophy to own the best conceptual keys and logical procedures to understand the world, behave like suppliers of true knowledge of our existence and the world. It is as if they consider philosophical knowledge to be objectively true, and philosophical methods and techniques to be objectively effective to find truth.

Recent developments in informatics and software applications offer us nice metaphors to get a picture of how we give meanings to our world. 'Augmented reality' is a real time photo or video perception of a situation or event, while this 'real picture' is being overlayed by also real elements that are alien to the original situation or event. The watcher, however, sees a world in which all elements are real; he thinks to see the real world. Actually, human experience is a practice to 'augment' the world we perceive with virtual elements with which we appropriate the world in our value systems. Philosophy is exactly the human craftsmanship to offer basic tools for this kind of appropriation, - or it is exactly the opposite, the skeptical investigation of such appropriations and 'augmentations'. 
In the first case, the philosopher knows and propounds, in the second case the philosopher doubts and investigates.

Plato's cave metaphor is paradigmatic for philosophy, and for philosophical practice as well. Lahav gave his book the title 'Stepping out of Plato's cave'. He writes,

"we constantly interpret our world, and we do so automatically and thoughtlessly. These interpretations are useful - you must interpret your world if you want to live in it, and you better do so without taking too much time to think, or else you would never start doing what you should do. But often they are also our prison, because they represent a one-sided, narrow, superficial perspective. This comfortable yet constricted world can be called my 'perimeter'." (Lahav 2016 a: 41)

In his philosophical counseling, Lahav supports his guest to be aware of his or her working perimeter, as the cause of his or her problem or worries, and to find a way out of the perimeter prison. Actually, it is not enough to step beyond your perimeter and to change perimeters; Lahav's practice is about seeing the "inner dimension" of the perimeter (Lahav 2016 b: 107).

\section{Theme, concept, and argument}

I would say, that in Lahav's practice, the philosophical quality of a philosophical conversation is in recognizing and phrasing the perimeter that is effective in my perception and conception of the world. The so-called "inner dimension" lies beyond it. This dimension of a perimeter is not my very personal dimension; the inner dimension is universally human, although it "may speak differently in different individuals".

"Therefore, I would need to learn the 'language' of the inner dimension as it speaks in my life." (Lahav 2016 b: 143).

Meeting someone in a philosophical counseling session, Lahav has something in his mind, and he believes that he can mean something 
to his guest, by offering her or him that idea of perimeters and the inner dimension. Actually, the guest's words are a screen on which the philosopher can project his perimeter slide and the inner dimension concept. The guest is seduced - by the power of philosophy, and by the philosopher's charm - to replace the meaning of her words with the meanings offered by the philosopher.

In Oscar Brenifier's interventions, the semantics is in the definitions of concepts and the dual logic of arguments. He questions the guest's words and sentences, without essential reference to the guest's experiences of the reality that is implied in his or her story. Actually, there is no story; right at the beginning the story is reduced to a question, and experiences are reduced to words and sentences with haphazardly chosen definitions and formal logic structures. The story is cut off the guest's world of experience. Brenifier's interventions are aimed at cleaning the guest's semantic knots and vagueness and lingering. He is a philosophical surgeon, cutting into the linguistic surface of the guest's words.

Anders Lindseth listens to the guest's words as expressions of his or her world of experience. He asks and stimulates his guest to tell about the experiences that are being expressed by his guest. On a certain moment, he introduces a theme in the conversation - a theme that he considers to be philosophical. And he tries to direct the dialogue towards this theme. He is not interested in cleaning semantic filters, just in the theme.

I leave out the theming, and stick to wandering with my guest in her or his landscape of experiences, and to the story telling. I am interested in getting the story richer and more transparent in the light of situations and events that are being experienced, remembered, and narrated by the guest. So, like Brenifier, my philosophical attention is focused on semantics; but, like Lindseth, my attention is also focused on the guest's experiences. Unlike 
Brenifier, I don not stick to the semantic and logic surface of the words and sentences; and unlike Lindseth, I do not direct the guest's attention to a theme.

\section{Lived situation, experience, recollection, narration}

To me the philosophy is in the way I perceive the other, listen to her story, take part in her story. What we share, here now in this situation of our encounter, are words. She remembers situations and events that bother her and that she wants to talk about with me. She took part in those situations, and she experienced them. Now she recollects those experiences. I hear her talking, and while listening, I get pictures and feelings of her experiences of those situations. (See figure 4.) Associations and thoughts happen. I experience her experiences (my experiences are not hers, but experiences of her experiences). I ask questions to be able to perceive and experience more of the situations and events she is talking about. I try to imagine the reality that is the 'source'or 'habitat' of her experiences and recollections and narration. Wandering in her narrated experiences, I wonder, get curious, ask questions, and try to tell my own experience of this virtual landscape. It might happen that I hear some of her words and that I do not see the 'real world' of her recollection. Those words cover what I want to discover. Maybe, it is covered in her own perception, too. Maybe, it is exactly that what she wants to be clear in that situation she is telling about. So, I ask questions and make remarks, hoping that she will uncover the covered. It is a matter of words. Do they cover or uncover what we want to understand? As a philosopher, I am a craftsman in the field of spotting and dismantling usages of words that cover what we want to understand. The human practice of narrating experiences is the habitat where I can practice my craft. 


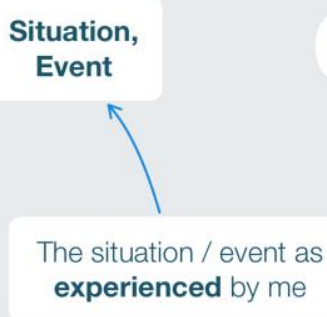

"Truth"

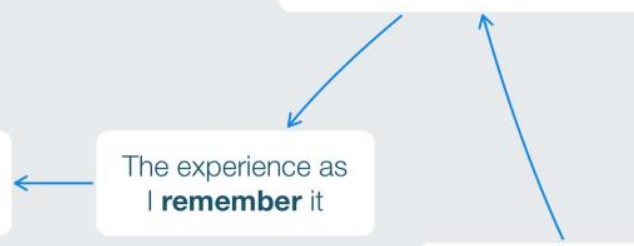

Cleaning the semantic filters

The narrative expression of my memory

\section{Semantic filtering}

Figure 4: The 'depth' of a story, and Semantic filtering and cleaning

\section{Non-philosophical embedding}

Where are we, in a philosophical universe, or in a basically nonphilosophical world?

We are here now, sitting in this room. At other times, we are walking in the woods, or having a lunch in a restaurant, or drinking a cup of coffee at yours, or accidentally meeting in the train, or wherever. Does it matter, that our dialogical encounter takes place in world that is more than us and our talking? Does it effect and influence our presence and dialogue, anyway? Maybe, it is even an inevitable condition of our philosophical encounter?

The philosophical universe

Some philosophers think that philosophy is about everything, or at least about the essential value and knowledge of everything. Name an issue that is important in human life, and - in the philosopher's 
mind - it turns out to be a philosophical issue, and thus, the philosopher's expertise. So, the philosopher's expertise encloses fields like truth, ethics, relationships, emotions, social behavior, society, politics, life and death, etc. Nowadays, a popular trend in philosophy, especially also under philosophical practitioners, is to consider philosophy 'the art of life'. Now, philosophy really is about the whole of human life. This philosopher is the holistic expert in the total field of human existence. I consider it rather arrogant to offer yourself as a philosopher who is an expert in the most essential and valuable issues of human life. Like Socrates and Wittgenstein I prefer a more humble view of philosophy.

Philosophical interventions in non-philosophical situations and events

Above, in paragraph 5, I mentioned a dialogical encounter between Lindseth and myself in Eisenach. It is interesting, that some students were surprised and confused by the fact that this dialogue was not a philosopher-guest setting. Lindseth and I were equivalent interlocutors. Neither of us was specifically the philosopher, nor the guest. We were colleagues and friends, both philosophizing about an issue that mattered both of us. In the field of philosophical practice it is custom to think about dialogical encounters as situations of service, assistance and care, and as a relation between a service provider, counselor or coach on the one hand and a customer or client on the other. Of course, dialogical philosophizing can be brought into action in such a kind of situation, but also in other kinds of situations. For example, in autumn 2015, when refugee flows from Syria and other Middle East and African countries entered the European Union, I happened to visit a friend of mine, to drink a cup of coffee after a walk with my dog. She started right away with a torrent of words against the refugees. The jargon of Dutch right-populist politician Geert 
Wilders was dominant in her tirade. I could have started a debate about her easy generalizations, social intolerance, and lack of hospitality. But I didn't. I went into the dialogical mode, and questioned about her life and experiences in relation to what she had said. It happened that she told her own story, without Wilder's political jargon. Now, I could understand why she said what she had said. It was easy to me to condemn Wilder's jargon, but it was impossible to me to criticize her experiences. The situation was not philosophical at all; we were just two friends talking about what bothered one of us. The only philosophical thing was, that I came into a dialogical mode, and that I took part in our conversation by entering her world of experience, and by treating her words in the light of what she was telling about, her living environment.

Levinas called ethics the first philosophy. In another text (Levinas 2013), he quotes De Waelhens, who says that before we philosophize we already are in an ethical relation towards the one we want to philosophize about. I prefer De Waelhens' idea. Being raised as a human being, I am socialized in a community (my family, my neighborhood, my city, my country, my cultural surroundings, my language community, and so on), that constituted my basic beliefs and world pictures, among them my moral attitude and standards. Maybe philosophy has helped me to reflect upon them, but certainly has not constituted them. I am already a believing, moral, and knowing part of the (human) world, before I start philosophizing about it.

In Socrates' and Wittgenstein's footsteps I consider the meaning of words, in relation to what we want to express, to be our 'material', and their assessment as our craft. Sometimes, our craft seems to help us and others to 'uncover' what was originally 'covered' by the way we used some words. Then, our philosophizing contributes to practices of life that we want to understand better - but the philosophizing certainly is not these practices of life; it is not life itself. 


\section{An attempt to categorize the field of philosophical practice}

In figure 5, I have summarized, in a schematic way, the two extreme philosophical positions in a choreography of a dialogical dance. I see myself as a Philosopher B, and call my way of doing the dance "narrative dialogical maieutics". My intention and attitude in dialogical philosophy are definitely maieutic. I focus on the other's experiences and his her narrating them.

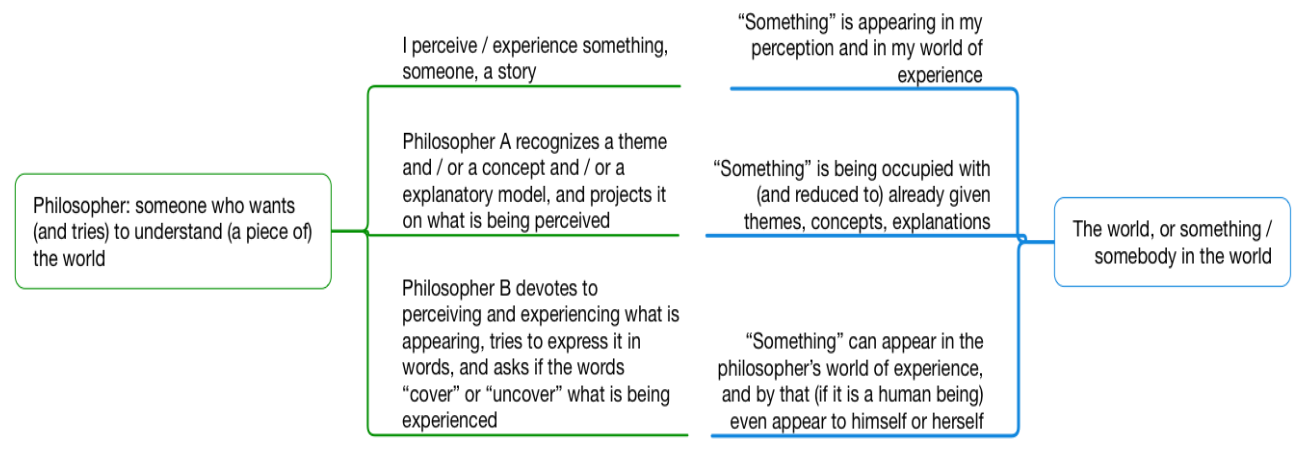

Figure 5: Two exemplary and contradictory choreographies in philosophy and philosophical practice; philosopher A and philosopher B.

\section{Further research}

How can we deepen and broaden our professional dialogues on the philosophical quality of philosophical practice?

The choreographic approach in this article can be confirmed, enlarged, and tested, by applying it to other examples of philosophical practice. The question about the philosophical quality of philosophical practice can be deepened by quantitatively and 
qualitatively broader and deeper research. How do philosophical practitioners justify that quality? And would it be possible among practitioners to agree about common and shared criteria to typify our practices? In this article I distinguished a small set of parameters. In paragraph 9, I named the 'scores' of my own practice "narrative-dialogical maieutics". Is it possible and useful to name different types of philosophical practices this way?

\section{Summary}

In this article I proposed a parameter set to map the landscape of philosophical practices. I looked at encounters between philosophers and their interlocutors as being dialogical dances. By means of some parameters (see figure 2) I tried to describe philosophical dialogues in choreographic terms. In absence of sociological or anthropological research of philosophical dialogues, I used my experiences in the field of philosophical practice to get some intuitive empiricism. First, I referred to an intensive training course that took place in Eisenach, Germany, at the beginning of March 2018. Second, I referred to my knowledge of and experiences with the practices of some colleagues in philosophical practice, who I consider to be exemplary for typical positions in this field, i.e., Oscar Brenifier, Ran Lahav, Anders Lindseth, and myself. Besides, I referred to neo-Socratic practices to typify another method driven and concept focused way of doing philosophical conversations. At the end, I presented some thoughts on how to do further research in the field of philosophical practice in a choreographic way.

To close this article, I have to thank the participants in both the German group in Eisenach and my philosophical groups in the Netherlands for giving feedback on the thoughts I developed in this article. 


\section{References}

BRANDT, Daniel: Philosophische Praxis. Ihr Begriff und ihre Stellung zu den Psychotherapien,: Verlag Karl Alber, München, 2010.

DE HAAS, Leon: Situations and Experiences. Essays on Philosophical Practice, PlatoPraktijk, Roermond, 2013. E-book at the i-Tunes / iBooks stores and www.platopraktijk.nl.

DE HAAS, Leon: "Nietzsche und die Krise der Philosophischen Praxis", in GUTKNECHT, Thomas u.a. (Hg.): Philosophische Praxis als Existenzmitteilung, Jahrbuch der IGPP, Band 6, Münster, 2015. Pags. 83-104.

DE HAAS, Leon: "Philosophical practice as a way out of the aporia of Modern philosophy", in: DE MOOR, Mieke (dir.): Socrate à l'agora. Que peut la parole philosophique?, VRIN, Paris, 2017. (The essay has been re-published in De Haas 2018.) DE HAAS, Leon: Skeptical Interventions. A Critical View of Philosophical Practice, PlatoPraktijk, Roermond, 2018. E-book at the i-Tunes / iBooks stores and www.platopraktijk.nl.

HACK, Caroline: Philosophie auf dem Marktplatz. Versuch einer systematischen und rheoretischen Fundierung des Arbeitsfeldes 'philosophische Praxis' aus pragmatischer Perspektive, Königshausen \& Neumann, Würzburg, 2015.

LAHAV, Ran: Stepping out of Plato's cave. Philosophical Practice and Self-Transformation, Solfanelli, Chieti, 2016 (a).

LAHAV, Ran: Handbook of Philosophical-Contemplative Companionships. Principles, procedures, exercises, Solfanelli, Chieti, 2016 (b).

LEVINAS, Emmanuel: "La substitution", in LEVINAS, Emmanuel: Autrement qu'être ou au-delà de l'essence, Le Livre de Poche, Paris, 2013. Pags. 156-205. 
LINDSETH, Anders: Zur Sache der Philosophischen Praxis. Philosophieren mit ratsuchenden Menschen, Verlag Karl Alber, München, 2005.

NIETZSCHE, Friedrich: Über Wahrheit und Lüge in aussermoralischen Sinne, Reclam Verlag, Leipzig, 2015.

RAABE, Peter: Philosophy's Role in Counseling \& Psychotherapy, Jason Aranson, New York, 2014.

RHEE, Young E.: "Embodied Mind Theory as a Foudation of Philosophical Practice", in Journal of Humanities Therapy, Vol. 1, Chuncheon-si, 2010. Pags. 129-143. 